\title{
PLASMA COATING FORMATION BY THE DEPOSITION OF CATHODE MATERIAL ERODED THROUGH HIGH-CURRENT PULSED DISCHARGE
}

\author{
Yu.G. Chabak, V.I. Fedun, V.G. Efremenko, T.V. Pastukhova, B.V. Efremenko \\ Priazovskyi State Technical University, Mariupol, Ukraine
}

The paper analyzes the conditions for the formation of a coating obtained using an electrothermal axial plasma accelerator due to plasma transfer of cathode erosion products. It is shown that by using a cathode of low-melting materials with a high-current pulsed discharge, microdrops are formed and injected from the accelerator falling into the surface to be treated. When colliding with the surface, the drops acquire near-disk shape with a radius of up to $100 \mu \mathrm{m}$, cooling on the substrate at a speed of up to $10^{8} \mathrm{~K} / \mathrm{s}$. This leads to the formation in the drops of a supersaturated solid solution with nonequilibrium structure. The subsequent heat treatment of the coating can result in hardening phases precipitation from solid solution causing the increase in coating microhardness.

PACS: 52.77. - j, 62.20.Qp, 61.66.Dk, 64.70.Kb

\section{INTRODUCTION}

Surface engineering is increasingly being used as an effective approach for expanding the functionality of metal surfaces [1-3]. Plasma assisted technologies are widely used in practice of renovation and surface modification of metal parts through deposition of protective coatings [3-6]. These technologies include pulsed-plasma treatment (PPT) based on the generation of plasma pulses directed to the surface [7-10]. High energy density transferred to the surface by plasma pulse leads to ultra-highspeed heating followed by very fast cooling due to heat evacuation inward the bulk of substrate [11]. The result is a modification of the near-surface layer, i.e. changing its structure and properties [7, 11, 12].

Different devices are used for PPT as plasma source [13-15]. One of them is electrothermal axial plasma accelerator (EAPA) intended for different purposes, including both modification and protective coating deposition [5, 16-18]. The coating is formed by the vapors of EAPA inner chamber material as well as by the vapor and microdroplets of cathode material which are the result of high-current discharge inside the chamber. It is obvious that in this conditions the chemical composition and the structure of the coating are greatly influenced by the material of cathode which is the electrode axially positioned inside EAPA chamber. As a rule, refractory materials (mostly tungsten) are used for cathode in plasma accelerators $[1,13]$. In contrast, in $[5,16]$ it is shown that cathode should be made of material with low melting temperature. This facilitates the cathode surface melting which leads to increase in mass transfer by micro-droplets fraction. Subsequently the velocity of coating formation increases. These cathode materials may include the alloys containing eutectic structural constituents like white cast irons [5] and ledeburitic tool steel [16]. The chemical composition of these alloys allows to obtain the coating with high volume fraction of hard carbides which are necessary to improve the resistance to abrasive and abrasive-erosive wear [19-21].

It is found that PPT may lead to metastable structure in coating resulted from rapid crystallization of plasma transferred material (i. e. "solute trapping" effect [22, 23]). Depending on PPT regime different plasmachemical reaction may occur leading to specific phase state of the coating. It is important to understand the mechanisms and time-temperature conditions of microdroplets formation during the discharge in EAPA chamber. It would help the PPT prognosing and choosing optimal technological parameters. In this connection, the object of present work is a study of formation of cathode microdroplets in EAPA chamber and further coating formation on the metallic substrate.

\section{MATERIALS AND METHODS}

EAPA was used as plasma source in the present work. The design, electrical circuit and the working principles of EAPA are described in detailed in [5, 17, 24]. EAPA discharge chamber (current arrestor RTF-6-0.5/10U1) is the fibrobakelite tube which is pressed up with steel flanges from the both sides. The metallic road is coaxially inserted inside the chamber to be the cathode. The opposite flange is the anode. Different metals and alloys were used as cathode material, specifically $\mathrm{Al}, \mathrm{Cu}, \mathrm{Ti}$, $\mathrm{W}$, bronze, Ni-Cr, plane carbon steel 1020, $28 \% \mathrm{Cr}$ - cast iron. The coating was deposited on the specimens of 10x10x20 mm size made of hot rolled steel $75 \mathrm{Mn}(0.75 \% \mathrm{C}, 0.91 \% \mathrm{Mn}, 0.28 \% \mathrm{Si})$ or of $15 \% \mathrm{Cr}$ - cast iron.

The working regime parameters of PPT were: the voltage of discharge $\left(U_{\mathrm{o}}\right)$ (accumulated in $1.5 \mathrm{mF}$ capacitor) is up to $4.5 \mathrm{kV}$; current amplitude is up to $10 \mathrm{kA}$; the distance between the electrodes is $60 \mathrm{~mm}$; the distance from EAPA edge to the substrate is $50 \mathrm{~mm}$. The duration between the pulses was $30 \ldots 40 \mathrm{~s}$.

Photographing the ejection of a plasma flux out of EAPA was performed using a Nikon " $1 \mathrm{~s} 1$ " photocamera. The interval between the shots was $1 / 1200 \mathrm{~s}$. The microstructure of the samples after PPT was investigated using a Nikon "Eclipse M 200" optical microscope and a JEOL "JSM-6510 LV" scanning electron microscope.

\section{ANALYSIS OF EXPERIMENTAL RESULTS AND THE PHENOMENOLOGY OF PROCESSES}

During high-current pulsed discharge in EAPU an energy equal to $\sim 10 \mathrm{~kJ}$ is released during $\sim 10^{-3} \mathrm{~s}$ in a volume of $\sim 10 \mathrm{~cm}^{3}$ [11]. This leads to evaporation of the dielectric walls of the discharge chamber, to evaporation and melting of the electrodes (mainly the cathode) leading to plasma jet forming. 
The molten cathode material is carried away by the gas stream and, possibly, partially enters the inner surface of the discharge chamber, which leads to its intense heating at the points of contact with the liquid metal. Due to the intense evaporation of fibrobakelite, the melt particles are discarded from the wall and removed from the EAPU chamber by plasma flux along the axis of the tube. When conducting experiments metallization of the inner surface of the tube was not observed.

As high-speed shooting shows, when a gas outflows from the chamber within a few milliseconds, ejection of liquid metal drops occurs. The dynamics of the ejection of steel droplets from the EAPU is shown in Fig. 1 with time interval between the shots of $1 / 150 \mathrm{~s}$. Processing the results of high-speed shooting shows that the velocity of droplets reaches about $5 \mathrm{~m} / \mathrm{s}$.
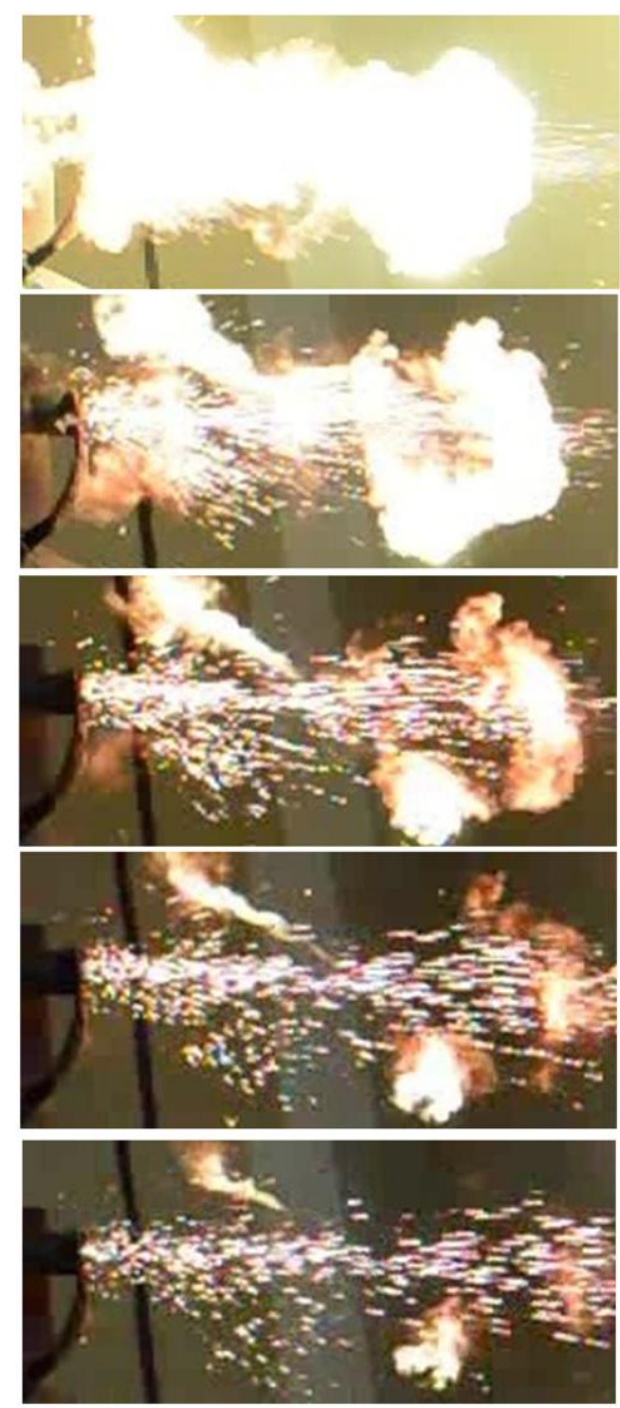

Fig. 1. Ejection of steel drops (plane steel 1020) from $E A P A\left(U_{o}=4 \mathrm{kV}\right)$

To assess the degree of plasma mass transfer, the central electrode was made of both drop-forming materials ( $\mathrm{Al}, \mathrm{Ti}$, bronze, cast iron, steel, $\mathrm{Ni}-\mathrm{Cr}$ ), as well as of slightly eroding refractory tungsten. Table 1 shows the values of specific erosion of cathode depending on the material. The specific erosion was found as cathode mass loss divided by the electric charge transferred during the discharge.
From Table 1 it follows that specific erosion is directly proportional to cathode material's melting temperature. From this dependence falls titanium, having an erosion value close to low-melting aluminium. This is probably due to the increased ability of titanium oxide to adsorb atmospheric gases upon heating [25].

Table 1

Specific erosion of materials of EAPA cathode

\begin{tabular}{|c|c|c|}
\hline Cathode material & $\begin{array}{c}\text { Specific ero- } \\
\text { sion, } \mathrm{Mg} / \mathrm{C}\end{array}$ & $\begin{array}{c}\text { Melting } \\
\text { temperature, }{ }^{\circ} \mathrm{C}\end{array}$ \\
\hline Steel 1020 & 4.37 & 1440 \\
\hline $\mathrm{Cu}$ & 6.35 & 1083 \\
\hline $\mathrm{Al}$ & 24.7 & 660 \\
\hline $\mathrm{Ti}$ & 20.7 & 1668 \\
\hline $\mathrm{Ni}-\mathrm{Cr}$ & 6.93 & 1390 \\
\hline Bronze & 7.64 & 950 \\
\hline
\end{tabular}

Metallographic studies show that after 10 plasma pulses using refractory tungsten cathode a thin coating with uneven thickness occurred on the surface of cast iron specimen (Fig. 2,a). For comparison, in Fig. 2,b shows the microstructure of the coating obtained using a cathode made of steel ASTM 1020. It can be seen that in the second case the thickness of the coating is about three times as high as in the first case with a greater uniformity of coating's thickness.
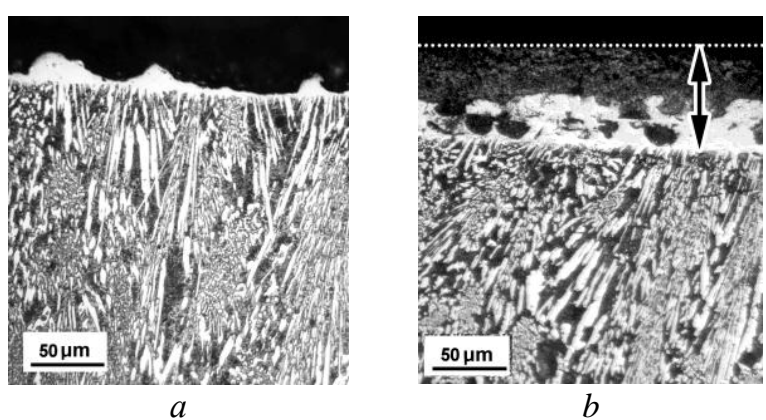

Fig. 2. The microstructure of the surface of highchromium cast iron treated with tungsten cathode (a) and cathode of steel ASTM $1020(\mathrm{~b})\left(U_{o}=4 \mathrm{kV}\right)$

To analyze the obtained experimental results, the following problems should be resolved, specifically: (a) the intensity of erosion of the central electrode (cathode); (b) the formation and acceleration of erosion drops; (c) thermal impact of plasma flow on the substrate surface; (d) forming of the coating of cathode material on substrate surface.

Erosion of the central electrode (cathode). Let us estimate the consumption of the material of the cathode in a single discharge realization. For low-melting materials the noticeable erosion is observed on an area of about $1 \mathrm{~cm}^{2}$ (Fig. 3). It is obvious that through this area the main charge transfer takes place, accompanied by intensive ion bombardment. In this case, the energy is transferred to cathode surface both due to the ions kinetic energy and due to their recharge [26]. 


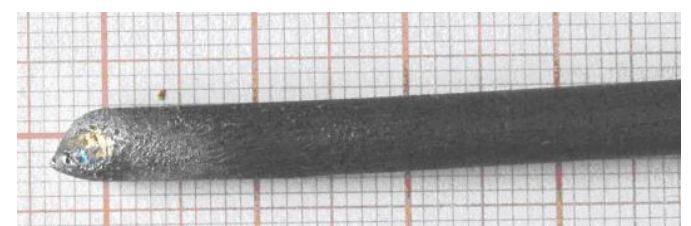

Fig. 3. The working part of the cathode made of steel ASTM 1020

Then, in a unit of time, the entire current-receiving region receives energy due to the kinetic energy of the ions:

$$
g_{k}=I_{+} U_{c} a_{k}
$$

and due to ions recharge:

$$
g_{n}=I_{+}\left(U_{i}-\varphi\right) a_{n},
$$

where $I_{+}$is the ion current which is about $10 \%$ of the total current; $U_{c} \cong 100 \mathrm{~V}$ is cathode potential drop; $U_{i} \cong 14 \mathrm{~V}$ is ionization potential of gases-vapours of the material of the dielectric chamber $\left(\mathrm{N}_{2}, \mathrm{H}_{2}, \mathrm{CO}_{2}\right.$, etc. $) ; \varphi$ is the electron work function of the cathode material $(\varphi \cong 5 \ldots 10 \mathrm{~V}) ; a_{\mathrm{k}} \cong 1$ and $a_{\mathrm{n}} \cong 0.5$ are the corresponding accommodation coefficients [26].

Therefore, the considered section of the cathode surface during the discharge time $t_{\mathrm{p}} \approx 0.5 \ldots 1 \mathrm{~ms}$ will receive the energy equal to:

$E=\int_{0}^{t_{p}}\left(g_{n}+g_{n}\right) d t=\int_{0}^{t_{p}} I_{+}\left(U_{C} a_{k}+\left(U_{i}-\varphi\right) a_{k}\right) d l$.

Assuming that during the whole discharge the values of $U_{c}, U_{i}, \varphi, a_{\mathrm{k}}$, and $a_{n}$ remain unchanged, then:

$$
E=0.1\left(U_{C} a_{k}+\left(U_{i}-\varphi\right) a_{k}\right) q,
$$

where $q$ is the charge that passed through the circuit during the discharge.

If we assume that the energy $E$ is released instantly and locally on the metal surface, then according to [26] the mass $(M)$ of the molten cathode material can be estimated as:

$$
M=0.31 \frac{E}{c T_{L}}
$$

where $c$ and $T_{L}$ are the specific heat capacity and the melting point of the cathode material, accordingly.

Then the maximum possible value of specific erosion is:

$$
\left[\frac{M}{q}\right]_{\max }=0.031 \frac{\left(U_{C} a_{k}+\left(U_{i}-\varphi\right) a_{k}\right)}{c T_{L}} .
$$

The calculation by expression (6) for a steel (ASTM $1020)$ cathode $\left(c=462 \mathrm{~J} /(\mathrm{kg} \cdot \mathrm{K}), T_{L}=1663 \mathrm{~K}\right)$ gives the value of the maximum possible specific erosion equal to $6.1 \cdot 10^{-6} \mathrm{~kg} / \mathrm{C}$, which is close to the value of erosion determined empirically (see Table 1). These results show that the molten cathode material is almost completely carried away by the plasma from the central electrode. Some difference may be due to the peculiarities of the processes of formation of droplets and their evacuation by gas flow.
The following facts indicate the possibility of droplet formation in a pulsed discharge. First, the thin molten layer has a thickness $h$, which can be estimated from the melting area $\left(S_{\text {liq }}\right)$ :

$$
h=\frac{M}{\rho_{M} S_{l i q}} \approx \frac{\left[\frac{M}{q}\right]_{\max }}{\rho_{M} S_{l i q}} q,
$$

where $\rho_{M}$ is the melt density.

For example, for typical operation modes of EAPA $\left(C_{S E}=1.5 \mathrm{mF}, U_{o}=4 \mathrm{kV}, q=6 \mathrm{C}\right)$ using a steel cathode $\left(\rho_{M}=7850 \mathrm{~kg} / \mathrm{m}^{3}\right)$ with a melting area characteristic for EAPU, equal to about $10^{-4} \mathrm{~m}^{2}$, we have $h \approx 5 \cdot 10^{-5} \mathrm{~m}$.

The formation of a drop begins with the formation of a protrusion on the liquid surface (the radius of which, for simplicity, will be considered equal to the thickness of the molten layer). Then it is necessary that the pressure drop of the gas at the free end of the cathode and the melt boundary farthest from it should be comparable with the Laplace pressure:

$$
\Delta p_{1} \geq \frac{\sigma}{h}
$$

where $\sigma$ is the surface tension coefficient of liquid metal (for steel $\sigma \approx 1.8 \mathrm{~N} / \mathrm{m}$ ).

Then, for steel cathode:

$$
\Delta p_{1} \geq \frac{\sigma}{h}=\frac{1.8}{5 \cdot 10^{-5}}=3.6 \cdot 10^{4} \mathrm{~Pa} .
$$

Assume that the pressure drop along the cathode is uniform, i.e.:

$$
\frac{\Delta p_{1}}{\Delta p_{K}}=\frac{\Delta l_{1}}{\Delta l_{K}}
$$

where $\Delta p_{1}$ and $\Delta p_{K}$ are pressure drop along the melt and along the entire cathode, respectively; $\Delta l_{1}$ and $\Delta l_{K}$ are the length of the molten area $(\sim 10 \mathrm{~mm})$ and the length of the entire central electrode $(\sim 300 \mathrm{~mm})$, respectively.

When condition (10) is fulfilled, the pressure inside the chamber during the formation of droplets may differ from the atmospheric one by a value of about $10 \mathrm{~atm}$. This value does not contradict the data given in [25].

As shown in [28], droplets with a diameter of $d_{D}=1.89 h$ are formed from a flux of a diameter $h$. Consequently, the diameter of the droplets ejected from the EAPU can reach $100 \mu \mathrm{m}$.

Drop movement in the chamber of the accelerator. Ejection of droplets from the EAPA chamber (see Fig. 1) is provided by the outflowing gas flow. It is obvious that the gas flow is directed along the axis of the accelerator chamber. The movement of the liquid drop is provided by the gas pressure on its surface and gravity. It is easy to show that in this case the drop acceleration is much greater than the gravity acceleration. Consequently, gravity can be neglected. Then, not paying attention to the cause of pressure on the drop surface, its movement can be described by the Euler equation:

$$
\rho_{D} \frac{d v}{d t}=-\operatorname{grad} p
$$


where $\rho_{D}$ is material density; $v$ is the drop velocity.

The results of high-speed photography (see Fig. 1) show that the time $\Delta t_{\text {exit }}$ of flight of a drop inside the accelerator chamber is almost an order of magnitude shorter than the time of ejection of all drops. Indeed, when the distance between the electrodes is $l_{K A}=60 \mathrm{~mm}$, the value $\Delta t_{\text {exit }} \approx 2 l_{K A} / v \approx 2 \cdot 10^{-2} \mathrm{~s}$, which is an order of magnitude longer than the time of a high-current discharge, but significantly less than the duration of the ejection of all droplets. Then the outflow of gas from EAPU during the evacuating one drop can be considered as quasistationary. Since the droplets trajectories coincide with the gas flow direction inside the chamber, the previous equation can be integrated along the trajectory. As a result, the Bernoulli equation is obtained:

$$
\rho_{D} \frac{v^{2}}{2}=p_{K}-p_{0},
$$

where $p_{K}$ is the gas pressure near the cathode tip; $p_{o}$ is the atmospheric pressure at the edge of the chamber (the value of which is close to atmospheric).

Assuming that the velocity of steel drops ejecting from EAPU is approximately $5 \mathrm{~m} / \mathrm{s}$, taking into account (12), the pressure drop will be estimated as $\approx 8 \cdot 10^{4} \mathrm{~Pa}$. Note that the values of pressure drops $\Delta p_{1}$ and $\left(p_{K}-p_{o}\right)$, according to expressions (9) and (12), are comparable in magnitude.

Thus, the erosion of the central electrode (cathode) is due to an instantaneous (within less than $1 \mathrm{~ms}$ ) energy release on the surface area of the electrode near its end. The amount of erosion is determined by the physical properties of the cathode material, by the properties of the plasma-forming gas and the amount of charge passing through the discharge gap. The main role is played by the cathode surface melting. Due to the presence of a pressure gradient in EAPA chamber, the erosion droplets are formed, are torn away from cathode surface and are accelerated.

Collision of the drops with the substrate surface. Fig. 4 presents an image of steel droplets on a glass substrate obtained at $U_{o}=2 \mathrm{kV}$. The reduced charge voltage was chosen to obtain the solitary drops. As can be seen from Fig. 4, when colliding with a substrate substrate, the drop acquires near-disk shape. Let us estimate the geometrical dimensions of such disks, taking into account the transformation of drop energy.

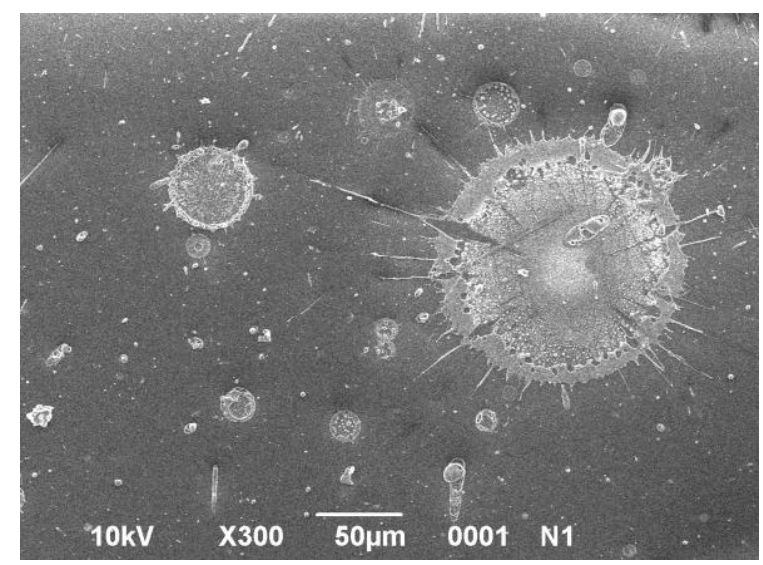

Fig. 4. Drops of ASTM 1020 steel on a glass substrate
The drop ejected from EAPA when approaching the substrate has kinetic energy $\left(E_{k}\right)$ and surface potential energy $\left(E_{\text {surf }}\right)$ :

$$
\begin{gathered}
E_{\kappa}=\frac{\rho_{D} V_{D} v^{2}}{2}=\frac{\rho_{D} \pi d_{D}^{3} v^{2}}{12}, \\
E_{\text {surf }}=\sigma S_{D}=\pi d_{D}^{2} \sigma,
\end{gathered}
$$

where $V_{D}$ and $S_{D}$ are the volume and surface area of the drop.

When colliding with an obstacle, the drop transformes into a stationary thin liquid disk of radius $R_{D H}$ and thickness of $h_{D H}<<R_{D H}$, whose surface energy is equal to $\pi R_{D H}^{2} \sigma$. Eliminating viscosity from consideration, according to energy conservation law, we have:

$$
\frac{1}{12} \rho_{D} \pi d_{D}^{3} v^{2}+\pi d_{D}^{2} \sigma=\pi R_{D H}^{2} \sigma
$$

or

$$
\frac{1}{2} \rho_{D} \frac{1}{6} \pi d_{D}^{3} v^{2}+6 \frac{1}{6} \pi d_{D}^{3} \frac{\sigma}{d_{D}}=\pi R_{D H}^{2} h_{D H} \frac{\sigma}{h_{D H}} .
$$

When dividing expression (15) by the drop volume $\left(V_{D}=\pi d_{D}^{3} / 6=\pi R_{D H}^{2} h_{D H}\right.$ ) we obtain:

$$
\frac{\rho_{D} v^{2}}{2}+6 \frac{\sigma}{d_{D}}=\frac{\sigma}{h_{D H}},
$$

from where the disk thickness is found as:

$$
h_{D H} \approx \frac{d_{D}}{6+\frac{d_{D}}{\sigma} \frac{\rho_{D} v}{2}} .
$$

It follows from (17) the thickness of the disk formed from a drop does not exceed 1/6 of the drop's diameter. So, taking into account the estimates (8), (11), and (14), the disk thickness is equal to:

$$
h_{D H} \approx \frac{1.89 \cdot 5 \cdot 10^{-5}}{6+\frac{5 \cdot 10^{-5}}{1.8} 8 \cdot 10^{4}} \approx 10^{-5} \mathrm{~m} .
$$

and its radius:

$$
R_{D H}=\sqrt{\frac{d_{D}^{3}}{6 h_{D H}}} \cdot 10^{-4} \mathrm{~m}
$$

The calculation according to (19) gives the valuesof the radius $(\approx 100 \mu \mathrm{m})$ which was confirmed experimentally. As follows from the analysis of Fig. 4, the radius of droplets frozen on a glass surface varies from 10 to $145 \mu \mathrm{m}$, which is close to calculated value.

Drop cooling on the substrate. For further consideration, the value of time interval $\Delta t_{\text {exit }}$ between drop separation and its exit from the EAPA chamber is of interest. When the distance between the electrodes $\left(l_{K A}\right)$ is $60 \mathrm{~mm}$, the $\Delta t_{\text {exit }}$ value is an order of magnitude longer than the time of a high-current discharge. Consequently, the effect of the plasma flow on the substrate and the processes occurring during the deposition of droplets on the substrate are separated in time. At the initial moment, the plasma flow expires from the EAPA, 
encountering an obstacle (substrate); at the second stage microdroplets are injected from the EAPU, falling on the substrate surface.

When a plasma flux collides with an obstacle (sample), the high-temperature gas causes ultra-fast heating of the surface. In a previously published paper [11], a method for calculating the thermal field in a steel sample heated by EAPA plasma pulse was presented. According to the calculations, with a heat flux density $\left(q_{o}\right)$ equal to $1.75 \cdot 10^{9} \mathrm{~W} / \mathrm{m}^{2}$, the metallic sample can melt to a depth of $10 \mu \mathrm{m}$. In addition to melting, the surface of the sample is also subjected to a force due to the dynamic pressure $p_{D}$, which is comparable in magnitude to the pressure in EAPA chamber (i.e., $p_{D} \sim 10^{6} \mathrm{~Pa}$ ). Then, taking into account the justification of the formula (10), we conclude that the sample surface can be covered with a molten layer of thickness

$$
h_{k p} \approx \frac{\sigma}{p_{D}}=\frac{1.8}{10^{6}} \approx 2 \cdot 10^{-6} \mathrm{~m} \text {. }
$$

The remaining amount of molten steel will be removed by the gas flow from the sample surface. Therefore, for determination of the temperature field at the moment of drops collision with the sample surface, comparable to $\Delta t_{\text {exit }}\left(\sim 2 \cdot 10^{-2} \mathrm{~s}\right)$, the most interesting is the mode of EAPA with $q_{o}=1.75 \cdot 10^{9} \mathrm{~W} / \mathrm{m}^{2}$. At this mode the melting point is reached only in near-surface layer of the sample. The results of such calculations (according to [11]) are shown in Fig. 5. It can be seen that $10 \mathrm{~ms}$ after the discharge, the temperature of the surface layers of the sample to a depth of $\sim 100 \mu \mathrm{m}$ can be considered constant. Thus, when a flying drop meets the sample surface, the temperature gradient is practically absent in the latter. This sets the initial conditions for calculating the velocity of erosion drop which are cooled on the substrate surface.

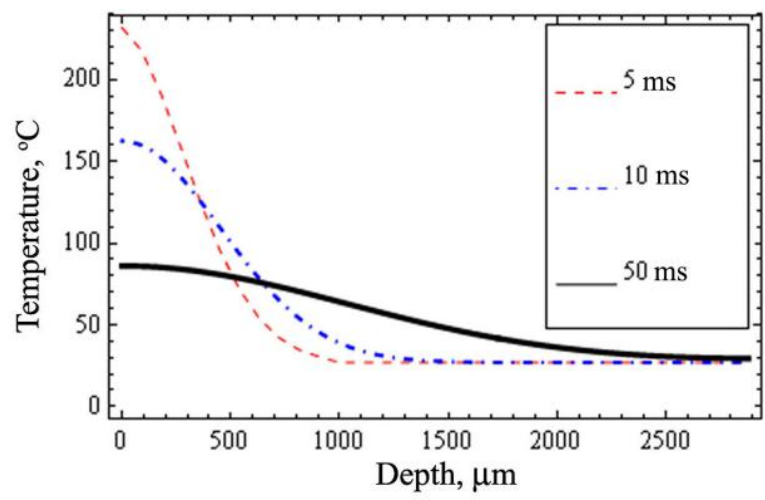

Fig. 5. Temperature fields in the sample bulk at time moment of 5, 10, and $50 \mathrm{~ms}$ after exposure to plasma flux at $q_{o}=1.75 \cdot 10^{9} \mathrm{~W} / \mathrm{m}^{2}$

As was shown above, the thickness of a disk formed from a drop is much smaller than its radius. Then the task of drop cooling is one-dimensional task of cooling a thin layer on a substrate, which is described by Fourier law:

$$
\rho c \frac{\partial T}{\partial t}=-\frac{\partial}{\partial x}\left[\lambda \frac{\partial T}{\partial x}\right],
$$

where $\rho$ is density, $c$ is specific heat capacity; $\lambda$ is thermal conductivity.
The velocity $V_{f}$ of "liquid-solid" interface movement is determined from equation:

$$
\rho \Lambda V_{f}=\lambda_{L}\left[\frac{\partial T}{\partial x}\right]-\lambda_{S}\left[\frac{\partial T}{\partial x}\right],
$$

where $\Lambda$ is the specific heat of fusion; $\lambda_{L}$ and $\lambda_{S}$ are the heat conductivity of the liquid and solid phases, respectively.

The initial conditions are given by the temperature distribution over the sample depth:

$$
T(x, 0)= \begin{cases}T_{1}, & 0<x<h_{D H}, \\ T_{2}, & x>h_{D H},\end{cases}
$$

where $T_{1}$ is the drop temperature, which exceeds the material melting point $\left(T_{1}>T_{\text {liq }}\right), T_{2}$ is the temperature of the substrate, previously heated by the plasma flux.

The solution of this task by the finite differences method according to an explicit scheme is presented in Figs. 6 and 7. The calculations were carried out at the following values: $T_{1}=2500 \mathrm{~K}, \quad T_{2}=373 \mathrm{~K}$, $h_{D H}=10 \mu \mathrm{m}$. The cathode and sample material was steel $75 \mathrm{Mn}$, for which $\rho=7830 \mathrm{~kg} / \mathrm{m}^{3}, \quad c=420 \mathrm{~J} /(\mathrm{kg} \cdot \mathrm{K})$, $\Lambda=140 \mathrm{~J} / \mathrm{kg}, \lambda_{L}=24 \mathrm{~W} \cdot \mathrm{m}^{-1} \cdot \mathrm{K}^{-1}$, and $\lambda_{S}=48 \mathrm{~W} \cdot \mathrm{m}^{-1} \cdot \mathrm{K}^{-1}$ [29].

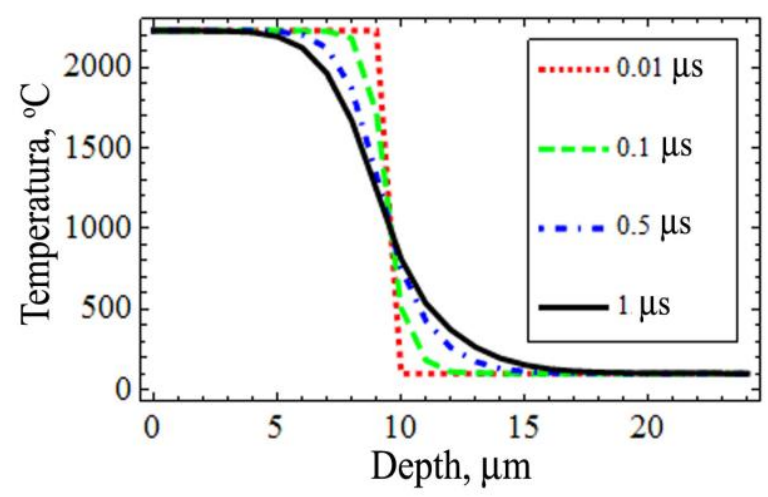

Fig. 6. Temperature field in sample bulk and inside the cooling drop after its deposition

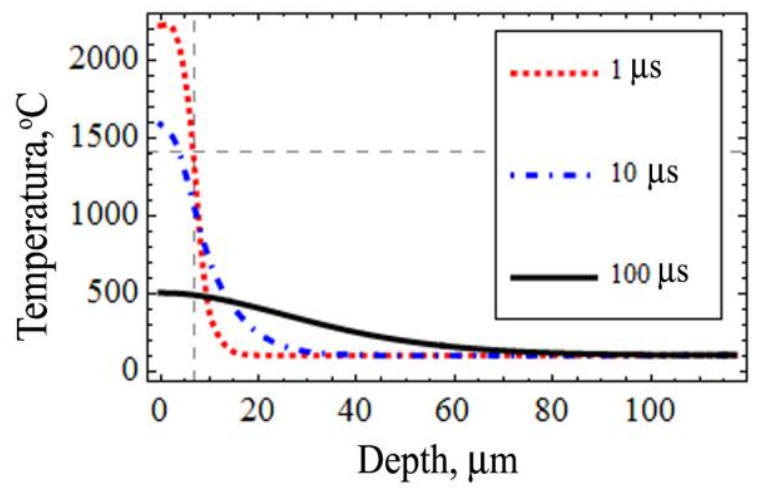

Fig. 7. Temperature fields in the sample bulk and inside the cooling drop at time moment of 1,10 , and $100 \mu \mathrm{s}$

As can be seen from these figures, the cooling rate of the droplet material reaches value of $10^{8} \mathrm{~K} / \mathrm{s}$, which is an order of magnitude greater than the rate of temperature change in the sample surface when exposed to a plasma flux. This creates the condition for the "freezing" the drop, when the crystallization of the coating proceeds by a non-equilibrium mechanism with the 
formation of a solid solution supersaturated with alloying and impurity elements $[30,31]$. Such a single-phase (austenitic) coating structure is formed when using the cathode of heterogeneous materials as T1 tool steel [16] or high-chromium cast iron [30]. These materials both contain large amount of carbide particles in the initial state (before PPT).

The evaporation of fibrobakelite from the inner wall of the tube increases the concentration of carbon in the plasma flux, Carbon is transferred to the substrate and enriches the crystallizing coating material. This significantly affects the microstructure of the coating, in particular, high-carbon acicular martensite is formed, the amount of carbides and the fraction of retaiend austenite increase, the stoichiometry of carbide inclusions changes, etc. $[5,16,30]$. Atmospheric nitrogen, which is similar to carbon in its influence on structure, can also affect it. As for the oxidation of the coating in contact with atmospheric oxygen, than the previous EDS studies of the high-chromium $(28 \% \mathrm{Cr})$ coating did not reveal any significant enrichment of it with oxygen $[5,30]$.

As an example, Fig. 8,a presents the microstructure of the coating obtained using the EAPA on substrate of $75 \mathrm{Mn}$ steel using a cathode made of high-chromium $(28 \% \mathrm{Cr})$ cast iron. After 10 pulses, a coating of $150 \ldots 170 \mu \mathrm{m}$ thick formed on the surface. It consists of austenite oversaturated with carbon and chromium with the microhardness not exceeding $650 \mathrm{HV}$.
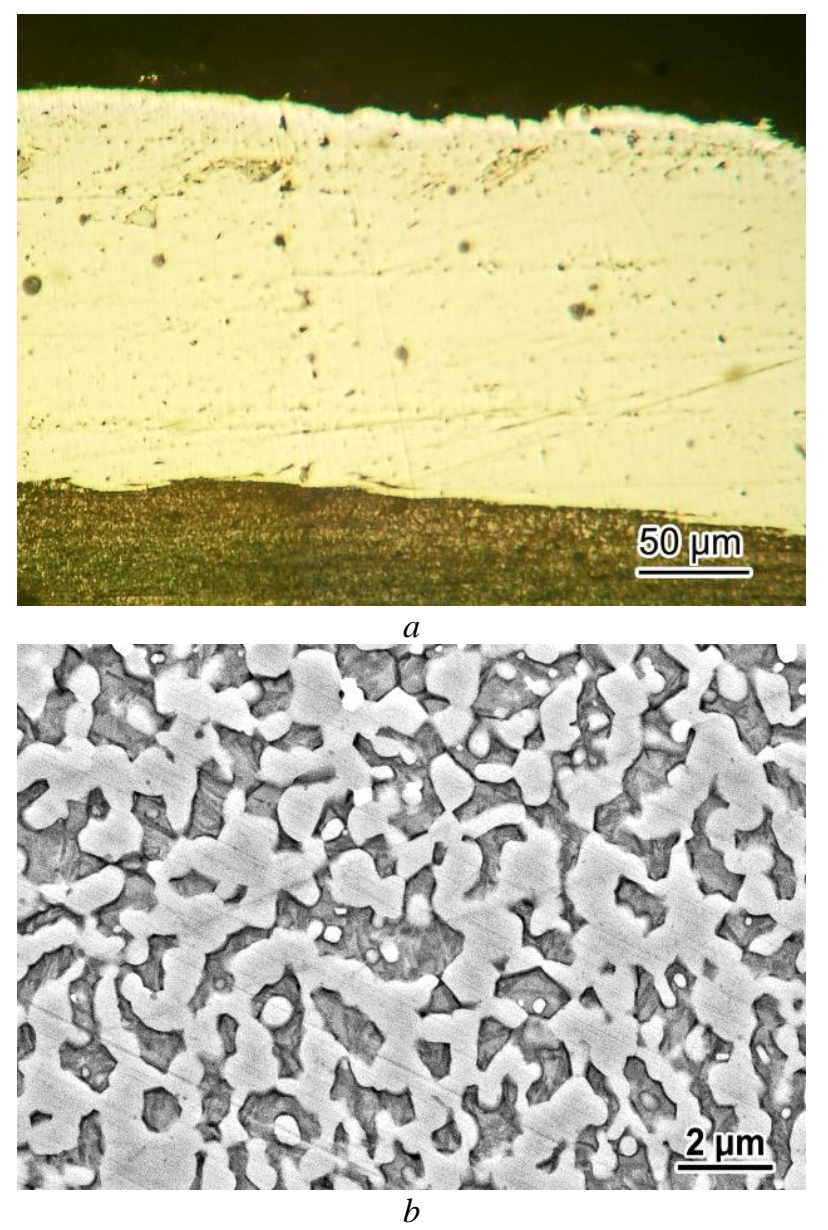

Fig. 8. Microstructure of the coating obtained on $75 \mathrm{Mn}$ steel using a cast iron $(28 \% \mathrm{Cr}$ ) cathode: after PPT (a), after PPT and holding at $950^{\circ} \mathrm{C}(\mathrm{b})$
The increasing coating microhardness and tribological characteristics requires an additional heat treatment to decompose the supersaturated solid solution with hardening phases precipitations and shear $\gamma \mathrm{Fe} \rightarrow \alpha \mathrm{Fe}$ phase transformation [32, 33]. In this case, the postplasma holding at $950{ }^{\circ} \mathrm{C}$ for $2 \mathrm{~h}$ led to the precipitation of a large number of carbides $(\mathrm{Cr}, \mathrm{Fe})_{7} \mathrm{C}_{3}$ in the coating with subsequent doubled increase in coating microhardness.

\section{CONCLUSIONS}

1. During high-current discharge a two-stage expiration of the plasma products from EAPA occurs. In the first stage, a high-temperature gas expires within $1 \mathrm{~ms}$, in the second stage (after $20 \mathrm{~ms}$ ) microdroplets formed due to erosion of electrodes are injected at a speed of $5 \mathrm{~m} / \mathrm{s}$.

2. The specific erosion of the EAPA cathode increases with a decrease in material melting temperature, reaching $25 \mathrm{mg} / \mathrm{C}$ for aluminum. Erosive transfer of the cathode material ensures the formation of a coating on the substrate.

3. Upon collision with the substrate surface, the erosion drops acquire near-disks shape with a radius of up to $100 \mu \mathrm{m}$. The rate of drops cooling on a metal substrate reaches $10^{8} \mathrm{~K} / \mathrm{s}$, which forms a coating with the structure of a supersaturated solid solution. Subsequent heating may cause decomposition of the solid solution with the precipitation of hardening phases and coating microhardness increase.

\section{REFERENCES}

1. O.D. Pogrebnyak, Yu.M. Tyurin. Pulsed-plasma modification of surface properties and coating deposition // Uspehi Fiziki Metallov. 2003, v. 4(1), p. 1-77 (in Russian).

2. M.V. Kindrachuk, Yu.Ya. Dushek, M.V. Luchka, A.N. Gladchenko. Evolution of the structure and properties of eutectic coatings during friction // Poroshkovaya Metallurgiya. 1995, N 5-6, p. 104-110 (in Russian).

3. Z.A. Duriagina, T.M. Kovbasyuk, S.A. Bespalov. The analysis of competitive methods of improvement of operational properties of functional layers of flat heating elements // Uspehi Fiziki Metallov. 2016, v. 17(1), p. 2951 (in Russian).

4. A. Anders. Fundamentals of pulsed plasmas for materials processing // Surface and Coatings Technology. 2004, v. 183(2-3), p. 301-311.

5. V.G. Efremenko, Yu.G. Chabak, A. Lekatou, A.E. Karantzalis, K. Shimizu, V.I. Fedun, A.Yu. Azarkhov, A.V. Efremenko. Pulsed plasma deposition of FeC-Cr-W coating on high-Cr-cast iron: Effect of layered morphology and heat treatment on the microstructure and hardness // Surface and Coating Technology. 2016, v. 304, p. 293-305.

6. B.G. Mellor. Surface Coatings for Protection Against Wear. Woodhead Publishing Ltd, 2006, p. 429.

7. А.В. Батраченко. Влияние импульсно-плазменной обработки на микроструктуру и свойства стали 65Г // Проблеми трибологї̈. 2014, №3, с. 86-92.

8. A.M. Zhukeshov, A.T. Gabdullina, A.U. Amrenova, S.A. Ibraimova. Hardening of structural steel by pulsed plasma treatment // Journal of Nano- and Elec- 
tronic Physics. 2014, v. 6(3), p. 03066-1-03066-3.

9. A.N. Bandura, O.V. Byrka, V.V. Chebotarev, I.E. Garkusha, V.A. Makhlaj, V. Medvedev, V.S. Taran, V.I. Tereshin, T.S. Skoblo, S.G. Pugach. Alloying and modification of structural materials under pulsed plasma treatment // International Journal of Plasma Environmental Science \& Technology. 2011, v. 5, N 1, p. 2-6.

10. J. Luo, Y. Chen, J. Xu, D. Lu. Effect of plasmapulsed detonation treatment on microstructure and properties of the Ti-6Al-4V surface // Surface and Coatings Technology. 2019, v. 366, p. 164-169.

11. Yu.G. Chabak, V.I. Fedun, T.V. Pastukhova, V.I. Zurnadzhy, S.P. Berezhnyy, V.G. Efremenko. Modification of steel surface by pulsed plasma heating // Problems of Atomic Science and Technology. Series "Physics of Radiation Effect and Radiation Materials Science”. 2017, N 4(110), p. 97-102.

12. S. Romankov, A. Mamaeva, S.D. Kaloshkin, S.V. Komarov. Pulsed plasma treatment of Ti-Al coatings produced by mechanical alloying method // Materials Letters. 2007, v. 61, p. 5288-5291.

13. K. Nowakowska-Langer, R. Chodun, K. Zdunek. Synthesis of multicomponent metallic layers during impulse plasma deposition // Materials Science-Poland. 2015, v. 6133(4), p. 841-846.

14. J. Kołek, M. Hołub. Practical design of a highvoltage pulsed power supply implementing $\mathrm{SiC}$ technology for atmospheric pressure plasma reactors // $\mathrm{Ap}$ plied Science. 2019, v. 9, p. 1451

15. M.G. Kovaleva, V.V. Sirota, V.M. Beresnev, Y.N. Tyurin, O.N. Vagina, I.A. Pavlenko. Improving the wear resistance of thermally sprayed nanocomposite $\mathrm{Cr}_{3} \mathrm{C}_{2}-25 \mathrm{NiCr}$ coatings by pulsed plasma treatment // Journal of Nano- and Electronic Physics. 2018, v. 10(6), p. 06035.

16. Yu.G. Chabak, V.I. Fedun, K. Shimizu, V.I. Zurnadzhy, V.G. Efremenko. Phase-structural composition of coating obtained by pulsed plasma treatment using eroded cathode of T1 high speed steel // Problems of Atomic Science and Technology. Series "Physics of Radiation Effect and Radiation Materials Science”. 2016, N 4(104), p. 100-106.

17. Yu.E. Kolyada, V.I. Fedun. Pulse electrothermal plasma accelerators and its application in scientific researches // Problems of Atomic Science and Technology. Series "Plasma Electronics and New Acceleration Methods”. 2015, N 4(98), p. 325-330.

18. Yu.E. Koljada, V.I. Fedun. Excitation of elastic pulses by powerful plasmoids in the acoustic waveguide // Problems of Atomic Science and Technology. Series "Plasma Electronics and New Acceleration Methods". 2008, N 4, p. 260-263.

19. V.G. Efremenko, K. Shimizu, A.P. Cheiliakh, T.V. Kozarevs'ka, Yu.G. Chabak, H. Hara, K. Kusumoto. Abrasive wear resistance of spheroidal vanadium carbide cast irons // Journal of Friction and Wear. 2013, v. 34, N 6, p. 466-474.

20. E.V. Sukhovaya. Structural approach to the development of wear-resistant composite materials // Journal of Superhard Materials. 2013, v. 35, N 5, p. 277-283.
21. V.G. Efremenko, K. Shimizu, T.V. Pastukhova, Yu.G. Chabak, K. Kusumoto, A.V. Efremenko. Effect of bulk heat treatment and plasma surface hardening on the microstructure and erosion wear resistance of complex-alloyed cast irons with spheroidal vanadium carbides // Journal of Friction and Wear. 2017, v. 38, N 1, p. 58-64.

22. M. Fenech, B. Mallia, M. Grech, J.C. Betts. The post-deposition heat treatment of co-deposited $\mathrm{Cr}_{3} \mathrm{C}_{2}$ and AISI 410 stainless steel using the coaxial laser deposition technique // Journal of Materials Science. 2013, v. 48, p. 2224-2235.

23. I. Hemmati, V. Ocelık, J. Th. M. De Hosson, Microstructural characterization of AISI 431 martensitic stainless steel laser-deposited coatings // Journal of Materials Science. 2011, v. 46, p. 3405-3414.

24. Yu.E. Kolyada, A.A. Bizyukov, O.N. Bulanchuk, V.I. Fedun. The use of a magnetic switch for commutation of high-current pulse circuits // Instruments and Experimental Techniques. 2001, v. 44(2), p. 213-214.

25. S.N. Lanin, E.V. Vlasenko, N.V. Kovaleva, Fam Tien Zung. The adsorption properties of titanium dioxide // Russian Journal of Physical Chemistry A, Focus on Chemistry. 2008, v. 82(12), p. 2152-2155.

26. И.А. Глебов, Ф.Г. Рутберг. Мощные генераторы плазмы. М.: «Энергоатомиздат», 1985, 153 с.

27. У. Юсупалиев, П.У. Юсупалиев., С.А. Шутеев. Импульсное осесимметричное истечение плотной плазмы в газовую среду. 2. Условия образования и устойчивость плазменного тороидального вихря // Журнал технической физики. 2007 , т.77, в. 1 , с. $50-62$.

28. С.К. Асланов. К теории распада жидкой струи на капли // Журнал технической физики. 1999, т. 69 , в. 11 , с. $132-133$.

29. В.С. Чиркин. Теплофизические свойства материалов ядерной техники: Справочник. М.: «Атомиздат», 1968, 484 с.

30. Yu.G. Chabak, V.G. Efremenko, K. Shimizu, A. Lekatou, T.V. Pastukhova, A.Yu. Azarkhov, V.I. Zurnadzhy. Comparative analysis of the microstructural features of $28 \mathrm{wt} . \% \mathrm{Cr}$ cast iron fabricated by pulsed plasma deposition and conventional casting // Journal of Materials Engineering and Performance. 2018, v. 27, N 2, p. 379-388

31. B. Vamsi Krishna, A. Bandyopadhyay. Surface modification of AISI 410 stainless steel using laser engineered net shaping $\left(\mathrm{LENS}^{\mathrm{TM}}\right.$ ) // Materials Design. 2009, v. 30, p. 1490-1496.

32. V.M. Beresnev, S.A. Klimenko, O.V. Sobol', S.V. Litovchenko, A.D. Pogrebnjak, P.A. Srebnyuk, D.A. Kolesnikov, A.A. Meilekhov, A.A. Postel'nik, U.S. Nemchenko. Influence of the high-temperature annealing on the structure and mechanical properties of vacuum-arc coatings from $\mathrm{Mo} /(\mathrm{Ti}+6 \mathrm{wt} . \% \mathrm{Si}) \mathrm{N} / /$ Journal of Superhard Materials. 2017, v. 39(3), p. 172-177.

33. Yu.G. Chabak, V.G. Efremenko. Change of secondary-carbides' nanostate in $14.5 \% \mathrm{Cr}$ cast iron at high-temperature heating // Metallofizika i Noveishie Tekhnologii. 2012, v. 34, p. 1205-1220 (in Russian). 


\title{
ФОРМИРОВАНИЕ ПЛАЗМЕННОГО ПОКРЫТИЯ ОСАЖДЕНИЕМ МАТЕРИАЛА КАТОДА, ЭРОДИРУЮЩЕГО ПРИ СИЛЬНОТОЧНОМ ИМПУЛЬСНОМ РАЗРЯДЕ
}

\author{
Ю.Г. Чабак, В.И. Федун, В.Г. Ефременко, Т.В. Пастухова, Б.В. Ефременко
}

Проанализированы условия формирования покрытия, получаемого с помощью электротермического аксиального плазменного ускорителя, за счет плазменного переноса продуктов эрозии катода. Показано, что в случае использования катода из легкоплавких материалов при сильноточном импульсном разряде образуются и инжектируются из ускорителя микрокапли, попадающие на обрабатываемую поверхность. При соударении с поверхностью они приобретают форму диска радиусом до 100 мкм, остывая на подложке со скоростью до $10^{8} \mathrm{~K} / \mathrm{c}$. Это приводит к формированию в каплях неравновесной структуры пересыщенного твердого раствора. Последующая термическая обработка покрытия может вызывать распад раствора с выделением упрочняющих фаз с соответствующим повышением микротвердости покрытия.

\section{ФОРМУВАННЯ ПЛАЗМОВОГО ПОКРИТТЯ ОСАДЖЕННЯМ МАТЕРІАЛУ КАТОДА, ЩО ЕРОДУСТЬСЯ ПРИ ПОТУЖНОСТРУМОВОМУ ІМПУЛЬСНОМУ РОЗРЯДІ}

\author{
Ю.Г. Чабак, В.І. Федун, В.Г. Ефременко, Т.В. Пастухова, Б.В. Ефременко
}

Проаналізовано умови формування покриття, що отримується за допомогою електротермічного аксіального плазмового прискорювача, за рахунок плазмового перенесення продуктів ерозії катода. Показано, що в разі використання катода 3 легкоплавких матеріалів при потужнострумовому імпульсному розряді утворюються і інжектуються із прискорювача мікрокраплі, що потрапляють на оброблювану поверхню. При зіткненні з поверхнею вони набувають форму диска радіусом до 100 мкм, охолоджуючись на підкладці зі швидкістю до $10^{8} \mathrm{~K} / \mathrm{c}$. Це призводить до формування в краплях нерівноважної структури пересиченого твердого розчину. Подальша термічна обробка покриття може викликати розпад розчину з виділенням зміцнюючих фаз з відповідним підвищенням мікротвердості покриття. 